\title{
Kontribusi Peradaban Andalusia terhadap Barat dan Kontekstualisasi Bagi Pendidikan Islam Masa Kini
}

\author{
Yazida Ichsan \\ Universitas Ahmad Dahlan Yogyakarta \\ *Correspondence address: yazida.ichsan@pai.uad.ac.id
}

\section{点㖞 \\ ISSN: $1979-4703$ (p) \\ ISSN: 2527-9726 (e)}

Keywords:

Andalusia, Civilization, Islamic Education, West

\section{A B S T R A C T}

The bistory of civilization during classical Islam experienced significant developments, especially during the Andalusian society. This article aims to describe the Andalusian civilization's glories and its contribution to the renaissance and Aufklarung's birth in the West and its contextualization to advance Islamic education today. This article is a literature research concerning historical literature sources. This study uses a beuristic approach, criticism, interpretation and histography. The analysis and discussion results show that Andalusia bas several forms of progress that Western impact progress, which includes several things. First, a civilization which is manifested in thoughts works of art, buildings and literature. Second, education adopted by Western nations through students. Third, a translation which revives the awareness of the use of ratio. As for the current educational context, the Andalusia civilization's implications contribute to an understanding of scientific reasoning, integrating qauliyyah, kauniyah and nafsiyyah logic by forming a learning climate being open to learning Western science without leaving the spiritual element in Islam.

\section{A B S T R A K}

Sejarah peradaban pada masa Islam klasik mengalami perkembangan signifikan, terutam pada masa peradaban Andalusia. Artikel ini bertujuan untuk mendeskripsikan kegemilangan peradaban Andalusia dan kontribusinya terhadap lahirnya renaissance dan aufklarung di Barat serta kontektualisasinya untuk memajukan pendidikan Islam masa kini. Artikel ini merupakan penelitian pustaka, dengan merujuk sumber literature sejarah. Studi ini menggunakan pendekatan heuristik, kritik, interpetasi dan histografi. Hasil analisis dan pembahasan menunjukkan bahwa terdapat beberapa bentuk kemajuan yang dimiliki Andalusia yang berdampak kemajuan Barat yang meliputi beberapa hal. Pertama, peradaban yang termanifestasikan dalam pemikiran, karya seni, bangunan dan satra. Kedua, Pendidikan yang diadopsi bangsa Barat melalui para pelajar. Ketiga, penerjemahan yang membangkitkan kembali kesadara penggunaan rasio. Adapun dalam konteks pendidikan saat ini, Implikasi peradaban Andaluasia memberikan sumbanagan akan kesadaran penggunaan nalar ilmiah, mengintegrasikan nalar qauliyyah, kauniyab dan nafsiyyah dengan membentuk iklim pembelajar dan terbuka untuk belajar ilmu pengetahuan Barat tanpa meninggalkan unsur spiritual dalam Islam. 


\section{Pendahuluan}

Secara alamiah, menjadi sebuah tabiat bahwa manusia merupakan makhluk madani yang memilki dimensi sipil dan sosial (Khaldun, 2011). Dalam prosesnya, interaksi manusia sebagai sebuah kebutuhan mutualisme yang termanifestasi pada kebudayaan dan peradaban. Effat Al-Sharqawi mendeskripsiskan bahwa kebudayaan memilki kecenderungan pada semangat mendalam masyarakat yang direfleksikan dalam bentuk moral, religi, sastra dan seni. Adapun peradaban lebih menekankan pada aspek kemajuan teknologi dan mekanis yang termanifestasi dalam bidang teknologi, ekonomi dan politik (Al-Sharqawi, 1986). Adapun dalam KBBI, peradaban sendiri dimaknai dengan kemajuan, kebudayaan, lahir dan batin (Poerwadarmin, 1991). Dalam Islam, istilah peradaban sangat erat dengan tamadun yang dideskripsikan dengan daerah atau wilayah yang memilki kemajuan dalam bidang intelektual, moral, sosial baik secara fisik dan non fisik yang berlandaskan nilai-nilai Islam (Nata, 2013).

Diskursus berkaitan dengan kontribusi Islam terhadap Barat menjadi objek yang sangat menarik untuk dikaji. Pergumulan pemikiran dan peradaban Islam dengan Yunani, Babilonia, Syiria, Persia, India dan Mesir memberikan warna dan ilmu pengetahuan baru bagi kemajuan peradaban Islam (Nakosteen, 2003). Dalam perspektif sejarah, pada Abad ke VII M sampai dengan Abad XII, umat Islam mengalami kejayaan dimana kemajuan pemikiran, ilmu pengetahuan dan teknologi menjadi mercusuar dan kiblat bagi bangsa di luar Islam baik di wilayah Timur dengan peradaban Abbasiyah dan Barat dengan Andaluasia. Islam menampilkan peranya sebagai agama yang shalibun likulli zaman wa makan. Bebeda dengan Eropa, pasca runtuhnya Romawi, golongan bangsawan, feodal dan kalangan gereja memposisikan fungsi akal bertentangan dengan ajaran Kristen yang menyebabkan masyarakat Barat mengalami kemunduran dalam segala aspek (Langgulung, 1987). Kondisi yang sedemikian memprihatinkan tersebut, menyebabkan bangsa Eropa berada pada Abad kegelapan dan kemunduran yang digambarkan dengan the dark of middle ages.

Kalangan tokoh agama sendiri bahkan mengkampanyekan perang terhadap ilmu pengetahuan (sains) dan filsafat dan menganggap bahwa kedua hal tersebut dianggap sihir. Beberapa kebijakan pun diberlakukan seperti pembakaran perpustakaan di Alexandria dan perpustakaan Kaisar Agusnius Caesar, penutupan sekolah-sekolah filsafat Athena dan larangan pengkajian terhadap karya Romawi dan Yunani Kuno (Suyanta, 2011). Dominasi gereja terhadap pendidikan di Eropa yang terbatas pada filsafat agama dan pendidikan akhlak, menutup peluang akal untuk mengkaji dan meneliti fenomenafenomena yang ada. Hal ini dibuktikan dengan sikap gereja yang sangat keras terhadap beberapa pernyataan Copernicus dan Galileo terkait bentuk bumi yang bulat dan bukan merupakan pusat tatasurya(Khadhar, 2005). Stagnansi perkembangan tersebut dilatarbelakangi pula dogma gereja yang mengharamkan filsafat dan ilmu pengetahuan Yunani (Yunus, 1989).

Hanya saja, pada Abad ke 17-19 M, umat Islam mengalami stagnansi dimana kemunduran pendidikan menjadi faktor yang menyebabkan umat Islam tidak berdaya. 
Selain itu, menjamurnya kejumudan berfikir, munculnya taqlid buta dan tidak adanya penghargaan terhadap pengetahuan ilmiah menyebabkan umat islam berapa pada lingkaran kejumudan yang tidak kunjung sembuh dari lukanya. Lahirnya disintegrasi antar umat Islam, konfrontasi antar dinasti, kemunduran pemikiran dan pengamalan beragama juga menjadi faktor krusial stagnansi peradaban Islam. Sementara bagi bangsa Barat, Eropa memasuki golden age, dengan memungut, memelihara, dan mengembangkan pemikiran rasional sehingga lahir renaissance, aufklarung dan revolusi industri (Kusdiana, 2013).

Renaissance sendiri merupakan istilah yang digunakan untuk mendeskripsikan dinamisasi yang terjadi pada masyarakat Eropa yang dimaknai dengan kelahiran kembali terhadap diskursus karya pemikiran Yunani Kuno dan Romawi Kuno seperti Aristoteles, Plato dan Plotinus (Suhelmi, 2007). Gebrakan yang sangat fundamental tersebut berdampak pada transformasi dalam bidang sosio-kultural dan saintek yang kemudian berdampak pada era Auflarung yang ditandai dengan gerakan filsafat yang mengedepankan akal untuk melakukan inovasi dalam semua aspek kehidupan manusia. Pada abad ke 18 muculah gerakan Aufklarung sebagai gerakan pencerahan yang mengeliminir. Cengkraman trandensi kaum agamawan dengan menanamkan dogtrin agama dengan tidak berpijak pada nilai-nilai rasional mulai ditinggalkan sehingga Eropa mengalami kemajuan. Ditemukannya benua Amerika dan Tanjung Harapan serta lahirnya revolusi industri dengan ditemukannya mesin uap, teknologi militer dan perkapalan menjadikan bangsa Eropa jauh melampaui peradaban Islam.

Periodeisasi sejarah Islam sebagaimana dikemukakan Harun Nasution terbagi menjadi tiga. Pertama, Periode Klasik dalam kurun waktu 650-1250 M dengan adanya ekspansi pada masa Khulafa Rasyidin, Ummayah, Abbasiyah sampai dengan Ummayah II. Kedua, Periode pertengahan 1250-1800 M diawali dengan Runtuhnya Baghdad dan berdirinya tiga kerajaan besar : Usmani, Safawi dan Mughal. Ketiga, periode modern 1800 M dimana umat Islam disadarkan akan upaya modernisasi sebagai dampak dari kemunduran Islam dan kemajuan Barat (Nasution, 1985). Permasalahan yang terjadi, periodeisasi sejarah Islam terkadang terdistorsi dengan stigma Barat dengan memberikan label fundamentalis, biadab, irasional, dan tidak memiliki peradaban terhadap Islam (Sardar, 1988) menyebabkan umat Islam sendiri berada pada status quo, kurang PD dan terbelenggu pada lebel terbelakang, jumud, konservatif dan menolak modernitas. Bagi kalangan tertentu, bahkan menganggap bahwa kemajuan yang dicapai dunia Barat merupakan hal yang harus ditinggalkan karena berdampak pada unstabilitas dalam bidang ekonomi, politik, keagamaan dan peradaban. Apabila kita tarik benang merah, sesungguhnya kemajuan Barat tidak terlepas dari kontribusi peradaban Islam salah satunya adalah peradaban Ummayah II di Spanyol melalui saluran pendidikan dan penerjemahan.

Kajian literer berkaitan dengan kontribusi peradaban Andalusia terhadap Barat dan kontekstualisasinya terhadap pendidikan masa kini pada dasarnya merupakan penelitian pustaka (library reseach) dengan merujuk sumber literature sejarah berkaitan dengan kemajuan peradaban Andalusia dan kontribusinya terhadap Barat. Adapun tujuan dari penelitian ini berusaha untuk mendeskripsikan kemajuan peradaban Andalusia sehingga 


\section{At-Taqaddum}

Vol. 12 No. 2 (2020) 113-134

menginspirasi bagi pendidikan Islam agar lebih maju. Selain itu, penelitian ini berusaha untuk memberikan pengetahuan historis bagaimana Islam memiliki peradaban yang sangat tinggi dan mulia.

\section{Metode Penelitian}

Metode yang digunakan adalah penelitian pustaka (library reseach), dengan merujuk sumber literature sejarah berkaitan dengan kemajuan peradaban Andalusia dan kontribusinya terhadap Barat. Penelitian ini dilakukan dengan cara menuliskan, mengklarifikasi, mereduksi dan menyajikan data yang diperoleh dari sumber data tertulis (Muhajir, 1989). Sumber data primer pada penelitian ini adalah literature berkaitan dengan perkembangan peradaban, kontribusi dan kontekstualisasi daulah Ummayah II di Andalusia. Adapun data skunder berupa buku-buku dan jurnal penunjang berkaitan dengan sejarah Andalusia secara umum (Moleong, 2002). Dalam penelitian ini terdapat empat langkah yang digunakan dalam penelitian sejarah, yaitu : heuristik, kritik, interpetasi dan histografi dengan proses pengumpulan sumber dan fakta sejarah, melakukan verifikasi, melakukan penafsiran terhadap peristiwa sejarah dan menarik kesimpulan dengan menggunakan analisis kritis terhadap penelitian. Adapun metode yang digunakan dalam penelitian ini adalah metode dokumentasi yang dilakukan dengan mengumpulkan data dari sumber pustaka.

\section{Hasil dan Pembahasan}

Kajian berkaiatan dengan peradaban Andalusia, tidak terlepas dari sejarah, perkembangan, kemajuan dan kemunduruan kebudayaan dan peradaban. Selain itu kondisi pemerintah, masyarakat dan interaksi dengan dunia luar menjadi hal yang sangat berpengaruh secara signifikan dengan kemajuan peradapan Andalusia. Adapun secara lebih mendalam akan dijabarkan pada pembahasan sebagai berikut.

\section{Sejarah Andalusia}

Penakhlukan Andalusia, tidak terlepas dari kemajuan Dinasti Ummayah yang berkuasa di Damaskus (661-750 M). Di era Al-Walid bin Abdul Malik (705-715 M), ekspansi Daulah Ummayah membentang dari Afrika Utara menuju ke wilayah benua Eropa salah satunya adalah Spanyol. Sebelum abad ke lima Masehi, wilayah Spanyol dikenal dengan Iberia/Les Iberes yang disandarkan pada bangsa Iberia (penduduk tertua yang meninggali wilayah tersebut). Setelah ditakhlukkan Bangsa Romawi, dirubah dengan istilah Asbania. Adapun ketika kekuasaan berpindah ke bangsa Visgothic, Spanyol dikenal dengan Vandalusia yang disebut umat Islam yang menguasai Spanyol dengan Andalusia (Iqbal, 2011). Terdapat tiga teori berkaitan dengan asal-usul numenklatur Andalusia. Pertama merupakan kata serapan yang diambil dari salah satu bangsa Gothic 
yang berasal dari Jerman yang dikenal dengan Vandal/Wandal yang menguasai daerah Iberia (407-429 M) (Zidan, 2014). Kedua, merupakan arabisasi dari kata Atlantik. Ketiga, merupakan istilah tanah undian (Landablauts) yang digunakan bangsa Visigoth yang menguasai Iberia (Aizid, 2017).

Spanyol sendiri sebelum ditakhlukan Islam, berada dibawah kekuasaan Bangsa Romawi hingga abad ke lima Masehi, kemudian dikuasai bangsa Visighotic yang merupakan bangsa Jerman yang melakukan migrasi untuk mencari mata pencaharian dan pengembalaan dari dataran tinggi India menuju Eropa. Berbeda dengan Islam, kekuasaan bangsa Visighotic selama lebih dari dua ratus tahun tidaklah meninggalkan peradaban apapun(Zidan, 2014). Kekuasaan Islam menghadirkan peradaban yang sangat maju dengan menerapkan system pemerintahan yang berkeadilan dan toleran sehingga stabilitas keamanan relative terkendali.

Kondisi agama, ekonomi, pemerintahan dan masyarakat dibawah kerajaan Vishigotic dalam kondisi yang memprihatinkan. Dalam bidang agama, nuansa dikriminasi terhadap penganut agama aliran Monofisit dan Yahudi melahirkan violence dengan melakukan pemaksaan, penindasan, penyiksaan dan pembunuhan terhadap pemeluk aliran monofisit dan Yahudi. Kalangan agamawan dan kerajaan juga menyusun beberapa undang-undang dengan memaksa kaum yahudi masuk ke dalam Kristen (Yatim, 2006). Dalam Bidang Politik dan sosial, terjadi perpecahan disebabkan kudeta yang dilakukan Roderick terhadap Witiza yang menyebabakan penghianatan terhadap Roderick yang dikoordinir oleh Uskup Oppas (Hitti, 2002). Selain itu, terjadi konflik antara Ratu Julian dengan Roderick dilatarbelakangi tindakan asusila terhadap Florinda anak dari Julian. Penerapan politik feodal dengan system kasta menyebabkan masyarakat sangat menderita dengan beban pajak yang menjulang tinggi. Belum lagi para Uskup dan tokoh agama yang menduduki Majelis Nasional dan memiliki kewenangan memutuskan berbagai keputusan Negara dan pemilihan raja (Hasan, 2003).

Penakhlukkan Andalusia sendiri sebenarnya diawali dengan upaya penyerangan terhadap pemerintahan Raja Vampa, Arfanja, Eghica, dan Achila akan tetapi upaya tersebut belum berhasil (Hasan, 2003). Upaya penakhlukkan Andalusia baru berhasil pada masa Al-Walid bin Abdul Malik . Sebagai inisator pembuka gerbang Spanyol. atas perintah Musa bin Nusair, Tharif bin Malik melakukan ekspansi dengan membawa 500 pasukan dengan menaiki kapal yang disediakan Julian. Fase pertama Tharif bin Malik dapat menakhlukkan Eropa bagian selatan pada tahun 710 M. Keberhasilan Tharif kemudian ditindaklanjuti Thariq bin Ziyad melakukan ekspansi memimpin 7000 pasukan dan dapat mendapat di Jabal Thariq (Gibraltar). Setelah tiba di Andalusia, Thariq dapat menakhlukkan Roderick raja terakhir bangsa Visighotik di lembah Bakkah/Lakkah (Syalabi, 2003). Setelah itu, ia bersama pasukannya dapat menakhlukkan beberapa kota di Spanyol seperti : Cartagena, Algecras, Guadalete, Sidonia, Moron, Carmona, Alcala, Guadalajara, Ecija. Cordoba, Granada, Almunecar, Toledo dan Medinat al-Maida (Aizid, 2017). Dibawah komando Musa bin Nusair dengan sejumlah pasukan yang sangat besar, ia dapat menakhlukkan Marida, Barcelona, Arbola, Andiz dan Jaliqiya (Hasan, 2003). 


\section{At-Taqaddum}

Vol. 12 No. 2 (2020) 113-134

Beberapa sejarawan seperti Badri Yatim mengklasifikasikan menjadi 6 periode mengklasifikasikan periodeisasi perkembangan Islam di Andalusia menjadi beberapa periode, yaitu (Yatim, 2006):

Tabel 1. Periodeisasi Perkembangan Islam di Andalusia

\begin{tabular}{|c|c|c|}
\hline No & Periode & Keterangan \\
\hline 1 & $\begin{array}{l}\text { Periode } \\
\text { Pertama } \\
755 \mathrm{M})\end{array}$ & $\begin{array}{l}\text { Dipimpin oleh para wali yang ditunjuk khalifah Bani } \\
\text { Ummayah Damaskus. Merupakan masa perintisan, } \\
\text { penakhlukan dan perluasan wilayah Spanyol dari kerajaan } \\
\text { Visighotic. Stabilitas pemerintahan masih baik. Terjadi } \\
\text { beberapa konflik internal antara umat Islam sendiri karena } \\
\text { dilatarbelakangi perbedaan etnis dan golongan antara bangsa } \\
\text { Barbar dan Arab, suku Qaisy (Arab Utara) dan Yamani (Arab } \\
\text { Selatan). Selain itu terdapat pula gangguan stabilitas dari luar } \\
\text { Islam yang menyusun rencana dan kekuatan di daerah } \\
\text { pegunungan. }\end{array}$ \\
\hline
\end{tabular}

2 Periode Kedua Dibawah kepemimpinan amir keturunan Ummayah yang (755-912 M) tidak terikat dengan khalifah Bani Abbasiyyah. Merupakan masa kemajuan dalam berbagai aspek baik politik, infrastruktur dan iptek. Periode ini dipimpin oleh beberapa amir, yaitu; Abdurrahman Ad-Dakhil, Hisyam I, Hakam I, Abdurrahman II, Muhammad Bin Abdurrahman, Mundzir bin Muhammad dan Adbullah bin Muhammad.

3 Periode Ketiga Dibawah kekemimpinan khalifah, seperti Abdurrahman An(912-1013 M) Nashir (III) Hakam II dan Hisyam II. (masa keemasan dalam berbagai aspek) hingga munculnya Muluk. Thawaif sebagai dampak dari perpecahan internal kerajaan

4 Periode Dibawah pimpinan Muluk Thawaif yang terdiri dari NegaraKeempat negara kecil yang berpusat di Seville, Cordoba, Toledo. (1013-1086 M) Terjadi konflik internal antara satu kerajaan dengan kerajaan lainnya. Bahkan beberapa pihak yang bertikai meminta bantuan kerajaan Kristen.

5 Periode Kelima Pertama, munculnya dinasti Murabithun yang didirikan oleh (1086-1248 M) Yusuf bin Tasyfin di Afrika Utara dan dapat menguasai Spanyol dan dapat memukul mundur pasukan Castilia. Mengalami kemunduran dan keruntuhan tahun $1143 \mathrm{M}$ Kedua, dinasti Muwahhidun yang didirikan Muhammad bin Tumart di Afrika Utara. Dinasti ini dapat menguasai Spanyol 
6 Periode

Keenam

$(1248-1492)$ pasca runtuhnya Murabithun dibawah pimpinan Abdul Mun'im, Cordoba, Granada dan Almeria dapat dapat dikuasai. Akan tetapi pada tahun 1235, Muwwahidun mengalami keruntuhan di Spanyol dan kembali ke Afrika Utara

Dibawah pimpinan dinasti Bani Ahmar (1232-1492 M). Islam hanya menguasai wilayah Granada dan mengalami kehancuran karena konflik interen dimana Abu Abdullah Muhammad tidak terima ketika ayahnya menunjuk Muhammad bin Sa'ad menjadi putera mahkota. Dalam rangka menggulingkan kekuasaan Muhammad bin Sa'ad, ia meminta bantuan kepada Ferdinand dan Isabella. Setelah Abu Abdullah naik tahta, serangan dari kerajaan Kristen tak terbentung lagi, sehingga ia memutuskan untuk pergi ke Afrika Utara. Periode ini merupakan masa terakhir Islam di Spanyol

Berbeda dengan Badri Yatim, Musyrifah Sunanto membagi periodeisasi Andalusia menjadi tiga periode. Periode Pertama, periode wali dibawah kekuasaan Umayyah di Damaskus (711-755 M). Periode Kedua (755-1013 M) dibawah kekuasaan Ummayah II yang terdiri dari masa keamiran (755-912) dan kekhalifahan (912-1013). Adapun periode ketiga (1031-1492 M) dibawah Muluk Thawaif (1031-1086), dibawah dinasti Murabithun (1086-1235 M) dan dinasti Ahmar (1232-1492 M) (Sunanto, 2004). Sedangkan Syamruddin Nasution membagi menjadi empat periode : Pertama 710-755 M ketika umat Islam memasuki Spanyol sampai dengan terbentuknya daulah Ummayah di Andalusia. Kedua, 756-912 M sejak terbentuknya Dinasti Ummayah di Andalusia di bawah kekuasaan Amir. Ketiga 912-1012 M dibawah penguasa yang bergelar khalifah sejak Abdurrahman III hingga Muhammad II. Keempat 1009-1492 M dibawah Muluk Thawaif (Nasution, 2018).

Periodesasi tersebut menggambarkan beberapa kebijakan politis dan mendeskripsikan pola-pola kepemimpinan yang ada di Andalusia. Pada periode pertama, stabilitas negara masih mengalami gejolak baik dilatarbelakangi faktor internal maupun eksternal. Pertikaian antar kabilah Arab yang berasal dari kabilah Qais, Mudhar, Fihr dan antara kabilah Arab dan Barbar dalam perebutan kekuasaan menyebabkan adanya perpecahan antar umat Islam sendiri (Ali, 2018). Kemajuan Andalusia sebenarnya baru mengalami perubahan signifikan setelah datangnya Abdurrahman I yang dikenal dengan Abdurrahman Ad-Dhakbil dengan gelar Shakhar Quraisy yang dapat mendirikan dinasti baru tahun $138 \mathrm{H}$ (Hamka, 2016).

Pemindahan ibukota pemerintahan dari Toledo ke Cordoba menjadi langkah strategis untuk merealisasikan stabilitas politik, keamanan dan perkonomian. Pada masa ini, perhatian pembangunan infrastruktur, pengembangan ilmu pengetahuan, peningkatan kesejahteraan dan tatakelola menggambarkan mercusuar peradaban Islam 


\section{At-Taqaddum}

Vol. 12 No. 2 (2020) 113-134

yang sangat monumental (Ismail, 2017). Kejayaan tersebut kemudian dilanjutkan dengan periode-periode selanjutnya sampai dengan dinasti Bani Ahmar yang akhirnya sampai jatuhnya Granada dalam kekuasaan Kristen. Jatuhnya Granada dari kekuasaan Bani Ahmar 1492 M sebagai bentuk Reconquista, seluruh semenanjung Iberia menjadi babak baru bagi umat Islam, Kristen dan Yahudi. Dibawah kepemimpinan Ferdinand dan Isabella. Terjadi pengusiran terhadap kalangan Islam dan Yahudi. Bahkan umat hanya diberikan pilihan antara memeluk Kristen atau meninggalkan Spanyol untuk selamalamanya. Meskipun demikian peninggalan sejarah umat Islam sampai saat itu membuktikan bahwa secara historis, umat Islam pernah berjaya pada masa tersebut.

\section{Kemajuan Peradaban dan Pendidikan Andalusia}

Andalusia (Ummayah II) barang kali menjadi salah satu mercusuar peradaban yang dimilki Islam di Barat. Dalam perkembangannya, Andalusia menjadi hal yang sangat unik dimana peradaban dibangun oleh Hispano-Arab yang terdiri dari pergumulan Muslim, Kristen dan Yahudi (Munir Subarman, 2012). Selain itu, kebijakan penguasa terhadap pembangunan infrastruktur, penerjemahan, pendidikan dan lingkungan yang sangat kondusif, menjadi salah satu faktor yang melatarbelakangi kemajuan Andalusia. Adapun secara subtansial terdapat beberapa perkembangan dan kemajuan di Andalusia, yaitu:

1. Perkembangan Infrastruktur

Kemegahan bangunan yang dimilki Andalusia tercermin dari kebijakan pembangunan infrastuktur utama seperti istana Ja'fariyah, istana Al-Hamra, istana AlMakmun tembok Toledo, Madinah Az-Zahra, masjid Cordoba, masjid Seville dan jembatan Cordoba (Qantharah Ad-Dahr). Pada masa Abdurrahman II, pembangunan kota gencar dilakukan dengam memberikan sarana pendukung seperti masjid agung, perpustakaan dan lain sebagainya. Istana di lengkapi dengan taman, danau dan berbagai kamar. Akses jalan dilengkapi dengan pencahayaan disepanjang Istana.

Selain itu, pemerintah juga berkonsentrasi pada penyediaan fasilitas umum dengan membangun jalan umum, pasar dan tempat-tempat pemandian umum. Pada masa Abdurrahman Ad-Dakhil sendiri, terdapat 490 masjid yang kemudian berkembang secara kuantitas menjadi 3.837 masjid. Adapun rumah penduduk berjumlah 213.077, rumah ningrat 60.300, dan pertokoan berjumlah 80.455 (AsSirjani, 2012). Dalam hal pertanian, pemerintah membangun sistem irigasi dengan membangun dam, kanal, jembatan-jembatan air dengan pengaturan hidrolik menggunakan roda air untuk mengairi pertanian. Beberapa jenis buah-buahan dan hasil pertanian seperti apel, delima, ceri, kurma, pisang, kapas, tebu, ara, sutera dan rami. Kota Seville dan Cordoba menjadi kota yang sangat melimpah hasil produksi pertanian dan perindustrian internasional (Fauziah, 2016). Orang-orang Islam juga memperkenalkan pertanian padi dan jeruk. Andalusia juga mengembangkan dunia industri dalam bidang tekstil, logam, tembikar, kayu dan kulit untuk menyokong perekonomian (Yatim, 2006). Pada masa tersebut, didirikan pula pabrik tepung, kilang 
minyak (zaitul ma', zaitul badd dan zaitul matbukb), pabrik gelas, dan gading yang digunakan perabot mimbar dan pintu masjid (Salleh et al., 2018). Pada masa ini juga ditemukannya inovasi persenjataan berupa pistol yang dikenal dengan barud (Asy'ari, 2018).

Selain membangun Istana dan infrastruktur, kebijakan para khalifah juga mendirikan perpustakaan, lembaga pendididikan dan sarana pemandian dan tamantaman. Perpustakaan Di Cordoba sendiri memiliki 600 masjid, 900 tempat pemandian umum, dan 50 rumah sakit (Muammar, 2009). Istana juga dilengkapi dengan berbagai ornament ukiran yang menambah keindahan, kolam ikan, taman-taman dengan berbagai satwa, pabrik perhiasan dan persenjataan (Mubarok, 2004).

2. Perkembangan Iptek

Selain memiliki kemajuan peradaban yang berbentuk fisik, setidaknya pemerintahan Islam di Andalusia memilki kemajuan dalam bidang ilmu pengetahuan dan teknologi. kemajuan yang dimiliki Andalusia meliputi bidang filsafat, bahasa dan sastra, ilmu naqli, kedokteran, sains maupun arsitektur bangunan yang sangat indah. Dalam bidang filsafat dapat ditemui beberapa tokoh yang kelak memberikan kontribusi besar terhadap kemajuan Eropa, seperti Ibnu Masarrah, Ibnu Bajjah (Abu Bakar Muhammad bin Sayigh), Ibnu Tufail (Abu Bakar bin Thufail) dengan Hayy bin Yaqdzannya dan Ibnu Rusyd dengan karya monumentalnya Bidayatul Mujtabid dan Tahafut Tahafuti Falasifah. Dalam bidang kedokteran, mulai diterjemahkannya kitab Qanun karangan Ibnu Sina dan Al-Hawi karya Ar-Razi. Terdapat beberapa tokoh yang ahli dalam bidang kedokteran seperti Abul Qashim Zahrawi ahli bedah dengan at-Tasrif liman 'Ajiza 'ani Taklif yang merupakan ensiklopedi kedokteran yang terdiri dari tigapuluh jilid, Abu Marwan bin Zuhr dengan At-Taisir fil mudawat wa tatbir (Abdullah, 2018), Ibnu Khatima dan Ibnu Khatib yang menulis tentang penyakit epidemic (Aizid, 2017). Terdapat pula Ibnu Ja'far al-Ghafiqi seorang ahli pengobantan dengan kitab Al-Adawiyah Al-Mufrodah yang menerangkan berbagai macam obatobatan (Ramayulis, 2011). Bahkan dalam sebuah literatur dideskripsikan bahwa Don Sancho (955-967 M) yang merupakan raja kerajaan Leon memohon bantuan kepada kalangan dokter Khalifah Abdurrahman III untuk membantu mengobati penyakit obesitas yang dideritanya (Ismail, 2017).

Kemajuan dalam bidang sains juga ditandai dengan berkembangnya ilmu astronomi, geogarfi, matematika maupun kimia. Beberapa ilmuan bukan hanya ahli dalam satu disiplin ilmu, melainkan memiliki berbagai disiplin ilmu. Dalam bidang ilmu kimia dan astronomi kita dapati Abbas bin Firnas penemu kaca dari batu (Pulungan, 2019) dan penemu transportasi penerbangan meskipun belum sempurna (Abdul Syukur Al-Azizi, 2017). Az-Zarqalli ilmuan yang memperkenalkan astrolabe digunakan untuk mengukur jarak bintang dengan horizon bumi. Dalam bidang matematikan dan astronomi terdapat pula Abu Qasim Maslamah al-Majriti. Dikenal dengan al-hasib yang memberikan koreksi terhadap daftar astronomi Khwawrizmi. 
Terdapat pula Jabir bin Aflah yang mengarang buku al Hai'ah yang memberikan kontribusi dalam ilmu ukur sudut bidang datar dan lingkaran (Ismail, 2017).

Terdapat pula beberapa ilmuan di bidang sejarah, bahasa, sastra, dan kesenian. Dalam bidang sejarah dan sosiologi kita temukan beberapa ilmuan yang karyanya menjadi kajian hingga saat ini seperti Ibnu Khaldun dengan Muqqadimah, Ibnu Khatib, Ibnu Hayyan, Ibnu Qutyah dan Abu Walid bin Abdullah Al-Faradh (Aizid, 2017). Dalam bidang Bahasa dan Satra Al-Qali, Az-Zubaidi, Ibnu Malik, Ibnu Sayyidah, Ibnu Hajj dan lain sebagainya. Sedangkan di dalam bidang musik terdapat Hasan bin Nafi' yang dikenal dengan Ziryab.

3. Perkembangan Pendidikan

Setidaknya terdapat beberapa faktor yang melatarbelakangi maju dan berkembangnya pendidikan Islam di Andalusia sebagaimana pendapat Ramayulis. Pertama, dukungan dari pemerintah baik berupa kebijakan strategis maupun finansial sehingga masyarakat dapat mengakses penndidikan tanpa melihat dari latar belakang suku, ras dan agama. Bahkan pemerintah memberikan subsidi dalam bidang pendidikan dan memberikan penghargaan dan imbalan kepada para penulis dan penerjemah. Kedua, terdapat banyak sekolah dan perguruan tinggi yang terkenal dan sangat konsen dengan bidang keilmuan sehingga terjadi banyak dari kalangan sarjana berbondong-bondong belajar di Andalusia. Ketiga, adanya kompetisi secara positif di dalam memajukan peradaban dan pendidikan antara Ummayah II di Andalusia dan Abasiyyah di Baghdad. Keempat, kesadaran masyarakat akan urgensi menuntut ilmu dengan mempelajari berbagai bidang ilmu dan menghasilakn karya (Ramayulis, 2011).

Kecintaan para penguasa di Andalusia terhadap ilmu pengetahuan berimplikasi kepada beberapa kebijakan yang diterapkan proses pendidikan dan lembaga pendidikan. Dapat kikatakan bahwa maju mundurnya lembaga pendidikan di Andalusia bergantung pada interest patronase golongan penguasa terhadap pengembangan keilmuan. Kas Negara tidak hanya digunakan untuk pembiayaan infrastruktur saja, melainkan juga digunakan untuk pembiayaan pendidikan dan sarana penunjang. Pada masa Al-Hakam didirikan 27 Sekolah di Cordoba yang bertempat di masjid dimana seluruh siswa tidak dipungut biaya (Suwito, 2015). Khalifah Abdurrahaman III membangun universitas Cordoba dan perpustakaan di Granada dengan koleksi 600.000 kitab. Adapun Al-Hakam II (961-976 M), The Greatest Library di Eropa (Souyb, 1977). Setidaknya ia juga mendirikan 70 perpustakaan di wilayah Spanyol (Suwito, 2015). Selain itu, terdapat pula Khazanatul Humits Tsani dengan koleksi 400.000 jilid (Nizar, 2016). Mereka juga terlibat langsung dalam pengumpulan dan pembelian buku-buku ilmu pengetahuan serta menulis surat kepada para penulis agar mengirimkan karyanya dengan imbalan yang sangat tinggi (Yatim, 2006). Pada masa Al-Hakam II, terdapat kebijakan mengimport para guru dan professor dari AlAzhar dan Nidzamiyah untuk pengembangan pendidikan (Nizar, 2016). Terdapat pula perpustakaan Al-Hakim yang menyimpan koleksi buku ke dalam 40 kamar yang setiap kamar terdiri dari 18.000 buku (Syarif, 1979). 
Selain itu, terdapat beberapa Ilmuan seperti Abdul Wafa dan Hasdai yang direktrut untuk mengajar. Abdul Wafa sendiri merupakan seorang astronom, ahli matematika, dan translator karya Euclides dan Diophantus. Sedangkan Hasdai bin Shaprut merupakan fisikawan Yahudi dan transtlator yang menerjemahkan manuskrip Diocorides yang didiminta khalifah untuk menerjemahkan buku-buku Yunani. Para pendidik mendapatkan perhatian khusus dengan memperoleh gaji. Sumber gaji berasal dari sumbangan, penyewaan gedung dan hasil pertanian. Guru besar di lembaga pendidikan tinggi mendapatkan gaji sekitar 10 dinar perbulan. Adapun cendikiawan yang ahli dalam bidang filsafat tasawuf mendapatkan gaji sekitar 65 dinar. Sedangkan guru dilingkungan istana mendapatkan 1000 dirham perbulan (Munawar, et.al, 2017).

Sementara mayoritas penduduk Eropa buta huruf, hampir seluruh penduduk Andalusia dapat membaca dan menulis. Hal ini dilatarbelakangi kesadaran pemerintah dan masyarakat akan urgensi dari pendidikan dan kajian-kajian ilmiah. Hal tersebut dilatarbelakangi pula dengan fasilitas yang memadahi seperti perpustakaan dan lembaga pendidikan. Lahirnya perpustakaan sendiri dilatarbelakangi empat faktor utama. Pertama, kecintaan dan minat penduduk Andalusia terhadap pengumpulan buku-buku melahirkan budaya tulis-menulis. Kedua, kecintaan terhadap buku melahirkan kebutuhan akan perpustakaan. Ketiga, motivasi dan kepentingan pengumpulan buku-buku memberikan corak dan jenis perpustakaan yang berbedabeda. Keempat, kecintaan terhadap buku berdampak kepada pengentasa buta huruf dan penyebaran pendidikan (Masruri, 2006).

Pusat kegiatan pembelajaran dilakukan di masjid dengan berbagai aktifitas seperti diskusi, dialog dan perdebatan akademis. Dalam pendidikan formal para pendidik berdiri di podium dengan membaca manuskrip dan menerangkan secara detail. Setelah selesai, para penuntut ilmu diberikan kebebasan untuk bertanya, mengeluarkan pendapat bahkan berbeda pendapat dengan argument ilmiah. Sedangkan pendidikan nonformal dilakukan dengan model balaqah dimana guru mendiktekan buku (Nizar, 2016). Setidaknya terdapat tiga jenjang lembaga pendidikan yang berkembang pada masa itu. Pertama, kuttab merupakan lembaga pendidikan dasar yang mempelajari materi fiqh, bahasa dan sastra, musik dan kesenian. Kedua, madrasah yang tersebar di hampir seluruh wilayah Andalusi seperti Cordoba, Granada, Sevilla, dan Toledo (Yunus, 1989). Meskipun dalam beberapa literatur, madrasah baru dikenal pada pertengahan abad ke 14 yang diinisiasi oleh Yusuf Abu Hajjaj pada tahun 1349 M dengan membangun madrasah Granada. Ketiga, pendidikan tinggi seperti Universitas Cordoba yang memiliki berbagai jurusan seperti astronomi, matematika, kedokteran, teologi dan hukum dengan fasilitas perputakaan empat juta buku. Selain itu, Andalusia juga memiliki Universitas Sevilla, Malaga, Granada (Pulungan, 2019). Universitas juga dilengkapi dengan fasilitas pendukung seperti asrama, air bersih dan perlengkapan lainnya. Seperti universitas Cordoba yang menghabiskan 261.567 dinar sebagai biaaya pembangunan dan operasional (Septialona, 2016).

Ciri khas pendidikan Islam tidak terlepas dari elaborasi pengetahuan dengan adanya sinergitas normatifitas kewahyuan yang bersifat inklusif dengan persentuhan kebudayaan-kebudayaan setempat disertai dengan kajian ilmiah, metode eksperimental 
serta kajian mendalam berkaitan dengan kebudayaan di luar Islam (Samsu Nizar, 2016). Selain itu, persoalan politik antara Abbasiyah dengan Ummayyah Andalusia tidak menutup celah kepada para sarjana Spanyol untuk belajar ke wilayah Abbasiyah dan begitu pula sebaliknya sehingga secara langsung berpengaruh kepada kemajuan pendidikan (Siregar, 2016).

\section{Sumbangan Andalusia Terhadap Ilmu Pengetahuan dan Peradaban Barat}

Setidaknya terdapat tiga proses periode transmisi masuknya ilmu pengetahuan dan peradaban di Eropa yang berdampak pada terjadinya renaissance dan aufklarung bangsa Barat. Pertama, lawatan para sarjana Barat yang berbondong-bondong menimba ilmu dari dunia Islam dan kemudian mencloning beberapa bentuk kegiatan keilmuan yang dilakukan di Negara-negara Islam. Kedua, upaya adopsi pola dan bentuk-bentuk pengajaran, kurikulum maupun lembaga pendidikan yang dimilki umat Islam. Ketiga, proses transmisi ilmu pengetahuan melalui Perancis dan Italia dengan berkembangnya universitas-universitas dan kajian keilmuan (Asy'ari, 2018). Setidaknya terdapat tiga jalur utama transmisi Ilmu pengetahuan dan peradaban Islam terhadap Barat: Andalusia, Sisilia dan Perang Salib (As-Sirjani, 2012).

Pada abad ke 8 dan 9 peradaban Islam mengalami masa keemasan dengan menggabungkan tradisi Arab, Bizantium, Persia dan India dengan peradaban yang tinggi. Sementara itu, bangsa Eropa mengalami masa titik terendah. Bangsa Eropa dihadapkan pada perpecahan kekasiaran Romawi dan kemerosotan peradaban Greko-Romawi. Sekolah-sekolah mulai ditutup, hukum Romawi ditinggalkan, merebaknya buta huruf dan ditinggalkannya karya sastra klasik (Perry, 2012). Dominasi gereja terhadap pendidikan di Eropa yang terbatas pada filsafat agama dan pendidikan akhlak, menutup peluang akal untuk mengkaji dan meneliti fenomena-fenomena yang ada. Hal ini dibuktikan dengan sikap gereja yang sangat keras terhadap beberapa pernyataan Copernicus dan Galileo terkait bentuk bumi yang bulat dan bukan merupakan pusat tatasurya (Khadhar, 2005). Stagnansi perkembangan tersebut dilatarbelakangi pula dogma gereja yang mengharamkan filsafat dan ilmu pengetahuan Yunani (Yunus, 1989).

Renaissance sendiri merupakan istilah yang digunakan untuk mendeskripsikan dinamisasi yang terjadi pada masyarakat Eropa yang dimaknai dengan kelahiran kembali terhadap diskursus karya pemikiran Yunani Kuno dan Romawi Kuno seperti Aristoteles, Plato dan Plotinus (Suhelmi, 2007). Gebrakan yang sangat fundamental tersebut berdampak pada transformasi dalam bidang sosio-kultural dan saintek yang kemudian berdampak pada era Auflarung yang ditandai dengan gerakan filsafat yang mengedepankan akal untuk melakukan inovasi daloam semua aspek kehidupan manusia. Pada abad ke 18 muculah gerakan Aufklarung sebagai gerakan pencerahan. Lahirnya renaissance pertama kali di wilayah Italia yang secara geografis berdampingan dengan Peradaban Islam (Kusdiana, 2013). Setidaknya terdapat beberapa jalur transmisi pengetahuan yang secara lambat laun mempengaruhi. 


\section{Transmisi Pengetahuan Melalui Peradaban}

Kemegahan peradaban yang dimiliki Andalusia menjadi daya tarik tersendiri bagi penguasa Eropa. Pada masa Abdurrahman III, pendirian madina Az-Zahra yang memiliki 400 kamar dengan fasilitas pendukung seperti masjid, taman, danau, pabrik senjata dan perhiasan menjadi daya tarik tersendiri bagi bangsa Eropa. Bebarapa duta dari Italia maupun Jerman mendatangi tempat tersebut untuk menikmati keindahan dan kemegahan kota tersebut. Beberapa pemimpin Lyon, Nevar/Barcelona yang membutuhkan insinyur, arsitektur, ahli bedah, ahli musik mereka akan mendatangi Cordoba (As-Sirjani, 2012).

Pembangunan fasilitas umum seperti pasar, jalan, saluran irigasi, jembatan, dam, perguruan tinggi dan perpustakaan menyebabkan banyak pendududk Eropa datang untuk menimba ilmu. Dengan adanya perguruan tinggi para mahasiswa dari Asia, Eropa, muapun Afrika berduyun-duyun untuk memperoleh ilmu pengetahuan. Selain itu, beberapa bangunan dengan gaya arsitektur Andalusia masih dipertahankan hingga saat ini. Sebagai contoh masjid Agung Cordoba yang diubah menjadi Katedral Le Mezquita. Dalam bidang arsitektur, kemajuan peradaban Andalusia memberikan sumbangan terhadap desain diagonal lengkung dan diagonal rusuk sehingga bangunan tidak memerlukan tiang penyangga di tengah ruangan. Begitu pula dengan bangunan tinggi yang dimiliki Andalusia yang mengispirasi prototype menara Eiffel (Napitupulu, 2019). Begitu pula dengan perkembangan seni musik. Hasan bin Nafi' yang dikenal dengan Ziryab pendiri sekolah musik di Cordoba menginspirasi berdirinya sekolah musik di Valencia, Toledo dan Seville yang dalam prosesnya mempengaruhi seni music di Eropa (Aizid, 2017). Beberapa instrument music seperti gitar (gitara), Pndore (tanbur), lute (allud) serta musik mensural dan nilai-nilai mensural dalam not dan mode ritmik memiliki kontribusi penting bagi bangsa Barat (Nakosteen, 2003).

\section{Transmisi Pengetahuan Melalui Pendidikan}

Kemajemukan masyarakat Andalusia yang terdiri dari komunitas Arab, Barbar, Munvalldun, Shaqalibah, Yahudi dan Kristen Muzareb yang hidup secara berdampingan dalam balutan toleransi berimpikasi kepada kemajuan peradaban di Andalusia dari berbagai aspek (Yatim, 2006). Kebijakan Arabisasi dan memperlakukan ablu drimmah dengan baik memberikan kesempatan orang-orang Yahudi dan Kristen untuk berpartisipasi dan mengembangkan diri dalam memperoleh pengetahuan dan penerjemahan memberikan sumbangan yang tak ternilai harganya (Khadhar, 2005). Bahkan, terjadi pegeseran secara signifikan dari kajian Latin menuju penelitian tentang Arab. Mereka lebih tertarik mempelajari kepustakaan Arab dengan mengkaji pemikiran, filsafat dan bahasa Arab dan meninggalkan bahasa Latin (Arnold, 2019). Kesadaran akan ketertinggalan dunia Barat disikapi dengan usaha pengiriman mahasiswa untuk belajar di Andalusia seperti Gerard dari Cremono Italia, Johannes Hispalensis dari Seville, dan Dominic Gunsdisalvi dari Toledo (Ramayulis, 2011), Aberald dari Bath, Campanus dari Navarra, Albert dan Daniel dari Morey (Asy'ari, 2018). Beberapa kaum terpelajar tersebut 
kemudian menjadi motor perubahan bagi kemajuan Barat dan menerjemahkan bukubuku ilmuan Islam.

Kecintaan Hakam II terhadap Ilmu Pengetahuan dengan kebijakan pembangunan universitas menjadi daya tarik tersendiri dengan datangnya para pelajar Islam, Yahudi dan Kristen dari Eropa, Afrika maupun Asia (Mahmudunnasir, 1988) Setelah para pelajar dari Eropa kembali dari Andalusia, mereka mendirikan sekolah dan universitas salah satunya adalah universitas Paris yang merupakan universitas pertama di Eropa yang didirikan 1231 M. Di dalam universitas dikaji ilmu kedokteran, ilmu pasti dan filsafat (Yatim, 2006). Selain itu, jatuhnya Toldeo di bawah kekuasaan raja Alfonso VII, menjadi babak baru bagi transmisi intelektual bangsa Barat. Para penduduk asli Spanyol yang dikenal dengan Muzareb (mustaribun) yang memiliki berbagai disisplin keilmuan dalam berbagai bidang seperti kedokteran, pendidikan, filsafat, kimia dan lain sebagainya, ditugaskan untuk mengajar dan menerjemahkan literatur Arab ke bahasa Latin sehingga banyak pelajar Eropa yang belajar disana yang berdampak pada transmisi pengetahuan yang berjalan secara intensif. Di Toledo pula didirikan sekolah Tinggi Terjemah dibawah pimpinan Raymond (Sunanto, 2004).

Berdirinya universitas-universitas di Barat tidak lain muncul seiring dengan kegiatan penerjemahan dan ulasan karya muslim di dalam bidang ilmu pengetahuan, filsafat, teknologi dan teologi. Selain itu, ajaran Greco-Helenistik, Syiria-Zoroastrian dan Hindu melalui terjemahan, ulasan, komentar dan adaptasi muslim memberikan kontribusi bagi bangsa Barat. Berdirinya universitas Salermo (Bidang Kedokteran), Bologna (bidang hukum), Paris Montpellier, Padua, Naples dan Salamanca memiliki tujuan untuk memahami dan meanfaatkan ilmu pengetahuan klasik dan Islam dalam kitab-kitab terjemahan (Nakosteen, 2003). Abalard Bath ahli matematika dan filsafat yang merupakan salah satu produk pendidikan Islam di Toledo juga menginisiasi pendirian Universitas Cambridge dan Oxford. Begitu pula Petrus Alphonsi salah satu muzareb mendirikan perguruan tinggi di Inggris dengan mentransfer pengetahuan Islam (Huesin, 1981). Bahkan, di Universitas-universitas Eropa buku-buku terjemahan dari kalangan intelektual Islam menjadi rujukan. Pengembangan kurikulum secara revolusioner dengan mengembangkan beberapa bidang ilmu seperti matematika, kimia, fisika, astronomi, geografi, sejarah, filologi, teologi, musik dan filsafat memprakarsai lahirnya dunia baru di Eropa. Beberapa ilmuan Eropa bahkan menyerap berbagai ilmu pengetahuan dari ilmuan Muslim seperti Ibnu Rusyd, Al-Idris dan Al-Bakri, Ibnu Zuhr, Ibnu 'Arabi, Maimonides, dan Ibnu Jubair (Nakosteen, 2003).

\section{Transmisi Ilmu Pengetahuan dan Peradaban Melalui Aktifitas Terjemah}

Lahirnya Toledo Islamic Akademy of Translation di Andalusia menjadi salah satu faktor yang mengantarkan renaissance Eropa Pada abad ke dua belas dan ketiga belas, kota Toledo menjadi pusat aktifitas penerjemahan dari bahasa Arab ke bahasa Spanyol dan dari bahasa Spanyol ke bahasa Latin ataupun dari bahasa Arab ke bahasa Spanyol. Bukan hanya menerjemahkan karya-karya ilmuan Arab saja, melainkan juga buku terjemahan Yunani yang telah ditranslit dalam bahasa Arab seperti buku Hippocrates, Plato, 
Gallienus, Aristoteles, Euklid. Otto the Great yang merupakan Raja Jerman pada permulaan tahun 953 mengirimkan beberapa utusan untuk tinggal di Cordoba selama 3 tahun dengan misi mempelajari bahasa Arab dan membawa manuskrip untuk diterjemahkan di dipelajari secara mendalam ketika kembali ke Eropa (Ismail, 2017). Terdapat pula Jirarid Al-Karimuni yang dikenal dengan At-Tolitolo $(1150 \mathrm{M})$ dan Galipus yang menerjemahkan ratusan buku diantaranya Al-Manshuri karangan Ar-Razi dan dan Al-Qanun karangan Ibnu Sina dalam bidang kedokteran. Kebijakan tersebut juga diterapkan Alfonso X raja Castella (1252-1284). Dengan membentuk lembaga pendidikan tinggi dengan menerjemahkan buku-buku Arab ke dalam bahasa Latin dan Castella.

Para sarjana Barat seperti Gerard (Italia), Michael Scott (Inggris), Robert (Inggris), Adelard dari Bath dan Daniel Morly secara intensif menerjemahkan manuskrip Arab kedalam bahasa Latin dan memperkenalkan peradaban muslim ke Eropa diantaranya astronomi Khawarizmi, risalah matematis Khawarizmi dan empat belas buku Euclid (Nakosteen, 2003). Gerard sendiri menerjemahkan puluhan buku biologi, filsafat, astronomi, matematika dan ilmu kedokteran. Dalam bidang geometri, Gerard menerjemahkan 14 buku ulasan Euclid karya Abdul Baqi'. Ia juga menerjemahkan beberapa karya Zarqali yang dikenal Toledan Tables. Terdapat pula Raymund Lull dan Raymund Martin dua orang terpelajar yang mendorong masuknya pemikiran Ibnu Rusyd dan Al-Ghazali dalam pengembangan filsafat di Eropa. Raymund Lull sendiri merupakan orang pertama pendiri Sekolah Pelajaran Ilmu Islam. Adapun Raymund Martin merupakan mahasiswa lulusan pertama Sekolah Tinggi Toledo yang mendapat perintah dari Jendral Oerder of Preaches untuk menyalin Tabafut al-Falasifah karya Al-Ghazali dan Tahafut-Tahafut kaya Ibnu Rusyd (Huesin, 1981).

M. Michael Scott yang tinggal selama 15 tahun di Toledo dapat menerjemahkan komentar Ibnu Rusyd terhadap buku karangan Aristoteles dengan judul De coele et mundo .Adapun Robert mampu mengalihbahasakan Hisab Al Jabar wal Muqabalah karangan Khawarizmi (Ismail, 2017). Adelard of Bath Terdapat pula beberapa penerjemah yang bermigrasi dari Baghdad menuju ke Toledo seperti Ibnu Daud yang konsen dalam menerjemahkan buku astronomi dan astrologi (Sunanto, 2004). Dalam bidang kedokteran misalnya diterjemahkan buku-buku kedokteran seperti At-Tasrif liman 'Ajiza 'ani Taklif karya Abul Qashim Zahrawi yang berkaitan dengan ilmu bedah dan alat-alat pembedah, pos mortum bagi mayit dan mengetahui sebab meninggalnya. Kitab Al-Kuliyyatu Thib karangan Ibnu Rusyd Berkaitan dengan beberapa penyakit seperti cacar dan fungsi retina dan At-Taisif Fil Mudawati wa Tadbir karangan Ibnu Zuhr berkaitan dengan sensitive tulang dan mikrob kurab (Syarif, 1979).

Lahirnya gerakan Averroisme sebagai dampak dari banyaknya para pelajar yang datang ke Andalusia dan kegiatan penerjemahan memberikan kontribusi yang sangat berarti bagi kebangkitan dunia Eropa. Embrio gerakan ini sesungguhnya lahir pada abad ke 12 dengan banyaknya pengagum dan pengikut Ibnu Rusyd. Bahkan di dalam literatur sejarah, gerakan Averroisme memotivasi dan mendorong lahirnya reformasi dan rasionalisme pada abad ke 16 dan 17. Beberapa karya Ibnu Rusyd diterjemahkan dan dicetak di Venisia, Bologna, Napoli, Lyonms, Strabourg dan Jenewa pada abad ke 14-17 
M (Sudirman, 2011). Pemikiran-pemikiran Ibnu Rusyd menginspirasi penduduk Eropa untuk meninggalkan taqlid dan mengedepankan rasio yang telah lama terbelenggu. Bahkan, mayoritas perguruan tinggi yang didirikan di Eropa menjadikan pemikiran tokoh Islam seperti Al-Farabi, Ibnu Sina dan Ibnu Rusyd sebagai rujukan utama (Yatim, 2006). Ibnu Rusyd menawarkan nalar epistemologi burbani dimana aktifitas berfikir menghubungkan suatu premis dengan penalaran rasional yang sistematis, logis, dan berhubungan serta koheren dengan pengalaman yang ada. Dalam perspektif Ibnu Rusyd, objek pengetahuan terbagi menjadi dua yaitu inderawi (mudrak bil hawas) dan rasional (mudrak bin 'aql) (Iqbal, 2000).

\section{Kontekstualisasi Pendidikan Islam Masa Kini}

Diskursus berkaitan dengan Pendidikan Islam tidak terlepas dari optimalisasi fungsi manusia sebaga hamba, khalifah, nas, basyar, dan insan sebagai satu kesatuan yang tidak terpisahkan. Manusia yang secara komprehensif dapat mengomptimalkan fungsi akal, jiwa dan raga. Perumusan tujuan pendidikan Islam dalam perspektif M. Arifin memiliki empat konsekwensi logis. Pertama, berpijak pada tujuan dan fungsi manusia secara vertikal maupun horizontal. Kedua, sifat-sifat dasar manusia. Ketiga, kebutuhan masyarakat dan dinamika peradaban. Keempat, dimensi kehidupan manusia yang meliputi peningkatan kwalitas kehidupan dan kesejahteraan, mengandung nilai untuk tranformasi, dan keterpaduan kehidupan dunia-akhirat (Arifin, 1987).

Pendidikan Islam, sejatinya memberikan kontribusi bagi peradaban dunia dengan bernafaskan nilai-nilai spiritual dalam Islam. Dewasa ini, perkembangan revolusi industri dengan ditemukannaya mesin uap, penemuan listrik, komputerisasi, dan internet of thing menjadi babak baru bagi perkembangan teknologi dan ilmu pengetahuan. Hal tersebut berimplikasi pada lahirnya kecerdasan buatan (artificial intelligence), rekayasa genetika, super computer dan teknologi nano. Selain itu, berdampak pula pada lahirnya perubahan mindset, ideology, pemikiran, worldview. Sementara dalam konteks saat ini, setidaknya kita perlu pahami pula empat pola gerakan inteletual sebagaimana dikemukanan Abuddin Nata yang terdiri dari pola intelektualitas yang bersifat, integralistik, sparated/dikotomis, komprehensi dan akomodatif (Nata, 2016). Senada dengan pernyataan Fazlur Rahman, terdapat dua kutub berkaitan dengan pengetahuan modern berdasarkan perspektif muslim modern. Pertama, cara memperoleh pengetahuan modern hanya terpatok pada bidang teknologi praktis saja. Adapun dalam bidang pemikiran, umat Islam tidak memerlukan produk pemikiran barat, bahkan harus dihindari karena akan menimbulkan kerancuan dan keraguan dalam pikiran umat Islam. Kedua, umat Islam seharusnya tanpa ragu memperoleh pengetahuan modern dalam bidang teknologi maupun intelektualitas Barat mengingat transmisi pengetahuan dan kemajuan Barat tidak lain berasal pula dari kemajuan ilmuan Islam pada awal abad petengahan (Rahman, 1985).

Berkaca pada literatur sejarah, majunya peradaban Andalusia setidaknya tidak terlepas dari masyarakat yang memilki high culture dengan beberapa indikator. Pertama, kontribusi ilmuan di dalam mencerdaskan dan memajukan masyarakat. Kedua, penghormatan terhadap kepakaran ilmuan. Ketiga, pengangkatan pemimping yang 
memiliki kompetensi, ilmu, akhlak dan kebijaksanaan. Keempat, masyarakat memiliki kemajuan dan keterbukaan berfikir. Kelima, masyarakat memiliki kepribadian dan jati diri dengan nilai-nilai Islam dan pengetahuan (Muammar, 2009). Faktor tersebut menjadi dasar utama tegaknya pendidikan Islam, sehingga meskipun terjadi pola interaksi antara peradaban Yunani, Persia, Romawai, dan Islam, ciri khas Islam masih melekat pada umat Islam sendiri.

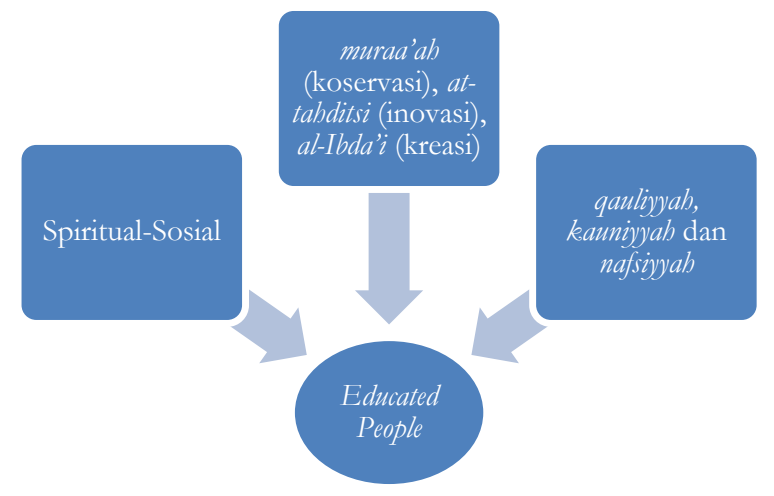

\section{Gambar 1. Pola Pendidikan Islam Masa Kini}

Apabila dikontekstualisasikan dengan pendidikan saat ini, maka terdapat beberapa alternative di dalam memajukan dan membentuk pola pendidikan Islam masa kini. Untuk membentuk educated people perlu penanaman nilai-nilai spiritual dan sosial dengan mengintegrasikan keilmuan qauliyyah, kauniyyah dan nafsiyyah. Keilmuan tersebut kemudian dikembangkan dengan prinsip mura'ah (konservasi), tabditsi (inovasi) dan ibda'i(kreasi). Terhadap nilai-nilai normative, perlu mengkaji kembali Al-Qur'an dan Sunnah sebagai sumber dasar utama tanpa mengesampingkan kajian turats. Sedangkan untuk ilmu pengetahuan dan teknologi prinsip tabditsi dan ibda'i dengan pendekatan ilmiah dan aplikatif. Bukan hanya bersifat teoritis, akan tetapi juga bersifat praktis, terbuka dan profan. Keilmuan tersebut perlu dibangun dengan menanamnkan kesadaran bagi individu maupun masyarakat sehingga terbentuk ke masyarakat pembelajar dimana akan terjadi polarisasi terhadap pengembangan ilmu pengetahuan. Sementara di masyarakat Indonesia saat ini, konsep pendidikan Islam yang dibangun lembaga pendidikan tidak berbanding lurus dengan kehidupan yang berjalan di masyarakat ataupun di lingkungan tempat tinggalnya. Iklim ilmiah dan amaliah dengan mendirikan komunitas-komunita belajar menjadi hal yang sangat penting sehingga umat Islam tidak mengenal tempat dan waktu untuk mengembangkan diri.

Umat Islam juga perlu ditanamkan kesadaran, bahwa kemajuan peradaban Andalusia, berkait-erat dengan majunya pemerintahan, pendidikan dan kegiatan penerjemahan. Umat Islam perlu berbenah dengan perubahan yang sangat dinamis dengan mengoptimalkan pengetahuan-pengetahuan yang ada untuk dikembangkan lebih baik dengan tanpa meninggalkan identitas keislaman. selaian itu keterbukaan terhadap dunia luar dengan tidak malu untuk belajar kepada peradaban lain menjadi kunci utama bagi kemajuan Islam. 


\section{Kesimpulan}

Transformasi kemajuan dan perkembangan Andalusia, tidak dapat dilepaskan dengan stabilitas pemerintahan yang dibangun dengan mengakomodasi pembangunan infrastruktur dan sumber daya manusia. Penghargaan terhadap ilmu pengetahuan dan teknologi yang termanifestasi dengan iklim belajar pada ranah grassroot, memberikan sumbangan yang sangat berharga bagi terbentuknya masyarakat yang berpendidikan. Selain itu, interaksi antara bangsa Arab dengan 'ajam di dalam kehidupan melalui kajian terjemahan kitab dan pendidikan melahirkan nalar keilmuan baru bagi Andalusia, tanpa menghilangkan nilai-nilai spiritual yang telah dibangun Islam. Melalui kajian ilmiah, metode eksperimental dan penekanan penggunaan akal, Andalusia tampil sebagai mercusuar peradaban Islam di belahan Barat. Kemajuan yang sangat signifikan tersebut, berdampak pada dijadikanya Andalusia sebagai salah satu jalur transmisi bagi kemajuan dan perkembangan Barat. Melalui peradaban, kitab terjemahan, pemikiran dan pendidikan, Andalusia memberikan kontribusi bagi lahirnya renaissance dan aufklarung di dunia Barat. Bila dikontektualisasikan bagi pendidikan Islam saat ini, umat Islam diharapkan memilki kesadaran akan urgensi membentuk iklim belajar yang ditanamkan sejak dini. Selain itu, pendidikan Islam seharusnya mampu mengintegrasikan nalar pengetahuan normative yang bersumber pada Al-Qur'an dan Sunnah dengan pemikiran rasional yang diimplementasi dalam bentuk eksperimen dan kajian empiris dan filosofis dengan pendekatan multidisipliner. Pendidikan seharusnya juga memberikan kesadaran kepada peserta agar tidak menutuk diri bagi perkembangan ilmu pengetahuan yang berjalan sangat dinamis dan massif tanpa menanggalkan unsur spiritual yang telah dibangun Islam. Dengan demikian, dalam konteks kekinian, umat Islam secara terbuka harus mengakui akan ketertinggalan dalam bidang IPTEK.

\section{Daftar Pustaka}

Abdullah, S. (2018). "Pembudayaan Ilmu Di Andalusia Dan Iktibarnya Untuk Pembangunan Tamadun di Malaysia ". Jumal PERADABAN, 11(1), 1-23. https://doi.org/10.22452/peradaban.vol11no1.1

Aizid, Rizem. (2017). Pesona Baghdad dan Andalusia: Meneropong Masa Kejayaan Islam Di Baghdad dan Andalusia. Yogyakarta: Diva Press.

Al-Sharqawi, Effat. (1986). Filsafat Kebudayaan Islam. Bandung: Penerbit Pustaka.Al-Azizi, Abdul Syukur. (2017). Sejarah Terlengkap Peradaban Islam. Yogyakarta: Noktah.

Arifin M. (1987). Filsafat Pendidikan Islam. Jakarta: Bina Aksara.

Arnold, Thomas W.. (2019). Sejarah Lengkap Penyebaran Islam di Dunia. Yogyakarta: IRiSoD. 
As-Sirjani, Raghib. (2012). Sumbangan Peradaban Islam Pada Dunia. Jakarta: Pustaka Al Kautsar.

Asy'ari, H. (2018). Renaisans Eropa dan Transmisi Keilmuan Islam ke Eropa. JUSPI (Jurnal Sejarah Peradaban Islam), 2(1), 1. https://doi.org/10.30829/j.v2i1.1792

Aziz, A., \& Munawar, T. H. (2017). PENDIDIKAN ISLAM ANDALUSIA : Sebuah Kajian Sosial-Historis Pendidikan Islam Masa Kejayaan Andalusia. Jois, 2.

Hamka. (2016). Sejarah Umat Islam Pra-Kenabian bingga Islam di Nusantara. Jakarta: Gema Insani.

Hasan, Hasan Ibrahim. (2003). Sejarah dan Kebudayaan Islam 2. Jakarta: Kalam Mulia.

Hitti, Philip K.. (2002). History of The Arabs. Jakarta: Serambi Ilmu Semesta.

Huesin, Oemar Amin. (1981). Kultur Islam: Sejarah Perkembangan Kebudayaan Islam dan Pengarubnya Dalam Dunia Internasional. Jakarta: Bulan Bintang.

Iqbal, Muhammad. (2011). Ibn Rusyd dan Averroisme. Medan: Citapustaka Media Perintis.Iqbal, Abu Muhammad. (2000). Pemikiran Pendidikan Islam: Gagasan-gagasan Besar Para Ilmuan Muslim. Yogyakarta: Pustaka Pelajar.

Ismail, Faisal. (2017). Sejarah dan Kebudayaan Islam Periode Klasike (Abad VII-XIII M. Yogyakarta: IRCiSoD.

Khadhar, Lathifah Ibrahim. (2005). Barat Memfitnah Islam. Jakarta: Gema Insani.

Khaldun, Muhammad Ibnu. (2011). Mukaddimah Ibnu Kbladun. Jakarta: Pustaka AlKautsar.

Kusdiana, Ading. (2013). Sejarah dan Kebudayaan Islam Periode Pertengahan. Bandung: Pustaka Setia.

Langgulung, Hasan. (1987). Asas-asas Pendidikan Islam. Jakarta: Pustaka Al Husna.

Mahmudunnasir, Syed. (1988). Islam Konsepsi dan Sejarahnya. Bandung: Rosda Bandung.

Masruri, Anis. (2006). Sejarah Perpustakaan Islam. Yogyakarta: Pokja Akademik UIN Sunan Kalijaga.

Moleong, Lexy J. (2002). Metodologi Penelitian Kualitatif. Bandung: Remaja Rosdakarya.

Muammar, K. (2009). Faktor Kegemilangan Tamadun Islam : Jurnal Hadhari, Bil. 2, 1531.

Mubarok, Jaih. (2004). Sejarah Peradaban Islam. Bandung: Pustaka Bani Quraisy.

Muhajir, Noeng. (1989). Metodologi Penelitian Kualitatif. Yogyakarta: Rake Sarasin.

Napitupulu, D. S. (2019). Romantika Sejarah Kejayaan Islam di Spanyol. MUKADIMAH: Jumal Pendidikan, Sejarah, Dan Ilmu-Ilmu Sosial, 3(1), 7-18. https://doi.org/10.30743/mkd.v3i1.886 
Nakosteen, Mehdi. (2003). Kontribusi Islam atas Dunia Intelektual Barat. Surabaya: Risalah Gusti.

Nasution, Harun. (1985). Islam Ditinjau Dari Berbagai Aspeknya. Jakarta: UI Press.

Nasution, Syamruddin. (2018). Sejarah Peradaban Islam. Jakarta: PT Raja Grafindo Persada.

Nata, Abuddin. (2013). Kapita Selekta Pendidikan Islam: Isu-isu Kontemporer Tentang Pendidikan Islam. Jakarta: PT Raja Grafindo Persada.

Nata, Abuddin. (2016). Sosiologi Pendidikan Islam. Jakarta: Rajagrafindo Persada.

Nizar, Samsu. (2016). Sejarah Pendidikan Islam Menelusuri Jejak Sejarah Pendidikan Era Rasulullah Sampai Indonesia. Jakarta: Prenadamedia Group.

Nur Dinah Fauziah, M. M. M. Z. (2016). PERADABAN ISLAM DI ANDALUSIA ( SPANYOL ) Nur Dinah Fañiah Muhammad Mujtaba Mitra Zuana PENDAHULUAN Setelah berakbirnya periode klasik Islam, ketika Islam mulai memasuki masa kemunduran, Eropa bangkit dari keterbelakangannya. Kebangkitan itu bukan saja. 1(1), 80-91.

Perry, Marvin. (2012). Peradaban Barat Dari Zaman Kuno Sampai Zaman Pencerahan. Yogyakarta: Kreasi Wacana.

Poerwadarmin, W.J.S.. (1991). Kamus Umum Bahasa Indonesia. Jakarta: Balai Pustaka.

Pulungan, Suyuthi. (2019). Sejarab Pendidikan Islam. Jakarta: Prenada Media Group.

Rahman, Fazlur. (1985). Islam dan Modernitas Tetang Transformasi Inteleketual. Bandung: Penerbit Pustaka.

Salleh, M. I., Wafi, M., Azman, N., Ihwani, S. S., Intelektual, M. Z. M. T., Pengaruh, A., \& Unisiti, D. A. (2018). Kewrujudan Sains dan Teknologi di Andalusia Mobd Iszatul Salleh, Mubd Wafi Nazrin Azman, \& Siti Subaila Ibwani. (April 2012).

Ramayulis. (2011). Sejarab Pendidikan Islam Napaktilas Perubahan Konsep, Filsafat dan Metodologi Pendidikan Islam Dari Era Nabi SAW sampai Ulama Nusantara. Jakarta: Kalam Mulia.

Sardar, Ziauddin. (1988). Tantangan Dunia Islam Abad 21. Bandung: Mizan.

Septialona, A. (2016). Arip Septialona Jurusan Sejarah Peradaban Islam IAIN Syekb Nurjati Cirebon. 4, 47-72.

Siregar, L. H. (2016). ANDALUSIA: Sejarah Interaksi Religius dan Linguistik. MIQOT: Jurnal Ilmu-Ilmu Keislaman, 37(2), 260-271. https://doi.org/10.30821/miqot.v37i2.93

Souyb, Josoef. (1977). Sejarah Daulat Umayah Di Cordoba. Jakarta: Bulan Bintang.

Subarman, Munir. (2012). Sejarah Peradaban Islam Klasik. Bandung: Alfabeta.

Sudirman. (2011). ISLAM DAN PERADABAN SPANYOL: Catatan Kritis Beberapa 
Faktor Penyebab Kesuksesan Islam Spanyol. Elharakah, 13, 17.

Suhelmi, Ahmad. (2007). Pemikiran Politik Barat. Jakarta: Gramedia,.

Sunanto, Musyrifah. (2004). Sejarah Islam Klasik: Perkembangan Ilmu Pengetahuan Islam. Jakarta: Prenada Media.

Suwito. (2015). Sejarah Sosial Pendidikan Islam. Jakarta: Prenada Media.

Suyanta, S. (2011). Transformasi Intelektual Islam ke Barat. Islam Futura, X No. 2, 1-16.

Syalabi, Ahmad. (2003). Sejarah dan Kebudayaan Islam. Jakarta: Pustaka Al Husna.

Syarif, M. M. (1979). Alam Fikiran Islam: Peranan Umat Islam Dalam Pengembangan Ilmu Pengetahuan. Bandung: Diponegoro.

Yatim, Badri. (2006). Sejarah Peradaban Islam. Jakarta: Garfindo Persada.

Yunus, Mahmud. (1989). Sejarah Pendidikan Islam. Jakarta: dakarya Agung.

Zidan, George. (2014). Sang Penakluk Andalusia. Jakarta: Pustaka Al-Kautsar. 
At-Taqaddum

Vol. 12 No. 2 (2020) 113-134

134 | P a g e 